\title{
THE DEVELOPMENT OF A PERFORMANCE MEASUREMENT SYSTEM FOR MAINTENANCE
}

\author{
J.K. Visser and M.W. Pretorius \\ Department of Engineering and Technology Management \\ University of Pretoria, Pretoria, 0002 \\ krige.visser@eng.up.ac.za, tinus.pretorius@eng.up.ac.za
}

\begin{abstract}
Business enterprises are under increasing pressure to become internationally competitive due to globalisation. World-class companies from abroad can now easily compete with local companies, introducing high quality products and services to the local community and industry. The pace of technological change is also forcing companies to increase productivity and to become more cost effective.

Performance management is part of the strategic management process in the business enterprise and the maintenance department therefore has to address this as part of the strategy formulation for the maintenance function. This paper outlines the strategic management process that is required in the maintenance department and defines a systematic process to develop a performance measurement system for maintenance.
\end{abstract}

\section{OPSOMMING}

Besigheidsondernemings is onder toenemende druk om internasionaal kompeterend te word weens globalisering. Wêreldklas maatskappye kan nou maklik met plaaslike maatskappye meeding deur hoë kwaliteit produkte en dienste aan die plaaslike gemeenskap en nywerheid te lewer. Die tempo van tegnologiese verandering dwing maatskappye ook om produktiwiteit te verhoog en meer koste-effektief te word.

Prestasiebestuur is deel van strategiese bestuur in 'n onderneming en die instandhoudingsafdeling moet derhalwe prestasiebestuur aanspreek as deel van die ontwikkeling van strategie vir die instandhoudingsfunksie. Hierdie artikel bespreek die strategiese bestuursproses soos benodig in die instandhoudingsafdeling en stel 'n sistematiese proses voor vir die ontwikkeling van 'n prestasiemetingstelsel vir instandhouding. 


\section{INTRODUCTION}

The maintenance function within many business enterprises is becoming increasingly important as the technical systems currently in use are nearing the end of their design lifes. Examples of such systems are a number of the coal-fired power stations, petrochemical refineries and smelters. These systems are large and complex and some of them are more than 30 years old. Increased age inevitably leads to an increased need for maintenance intervention to counter the effects of decreasing reliability due to wear out of equipment.

The maintenance function within most companies contributes significantly to the total costs of production or operations. Many mines have maintenance costs exceeding $40 \%$ of the total cost of production. Management needs relevant and quality information from the engineering and maintenance environment to optimise the costs. Only measuring the costs of maintenance is not sufficient and a total maintenance performance measurement system must be put into place to obtain quality information.

A system should be managed and control is one of the management functions. Control can only be achieved if there is an objective or goal for the system and if measurement and comparison takes place. For the maintenance system to be controlled properly there should therefore be objectives or goals for the maintenance system and actual performance should then be measured against these goals.

Performance measures should lead to effective decisions in the competitive environment that companies experience today. Performance measures influence what people do. Performance measurement should not be considered only as a means to provide information for management control and decision-making, but also as a powerful motivational tool driving decisions and actions that are consistent with the strategy of the organisation.

Maintenance is a complex function that involves a number of sub functions, such as the parts and materials store. Many indicators for measuring the outputs of the maintenance process are also not unique to maintenance and are partly production indicators as well, for example Availability, Reliability and Machine Utilisation.

\section{THEORY AND LITERATURE}

Many papers have been published in different fields of study on the problem of performance measurement and performance indicators in the manufacturing and management environment. Some of these references are discussed briefly in this paper as background to the development of a systematic process for the development of a performance measurement system for the maintenance function.

Management can be defined as the skill to plan, lead, organise and control human endeavour. Two important elements of management are goal setting and verifying achievement against goals. De Wet [1] sees, from an enterprise point of view, verification against goals as a direct analogue of classical feedback control systems. The essential operation of such a system is to ensure a minimum discrepancy between the goal and the output. The classical model however, refers to control information only. In order to incorporate more realistic features of the actual management process in an enterprise, the classical model can be expanded as 
shown in figure 1. This cybernetic model indicates the overall control process for a typical business enterprise.

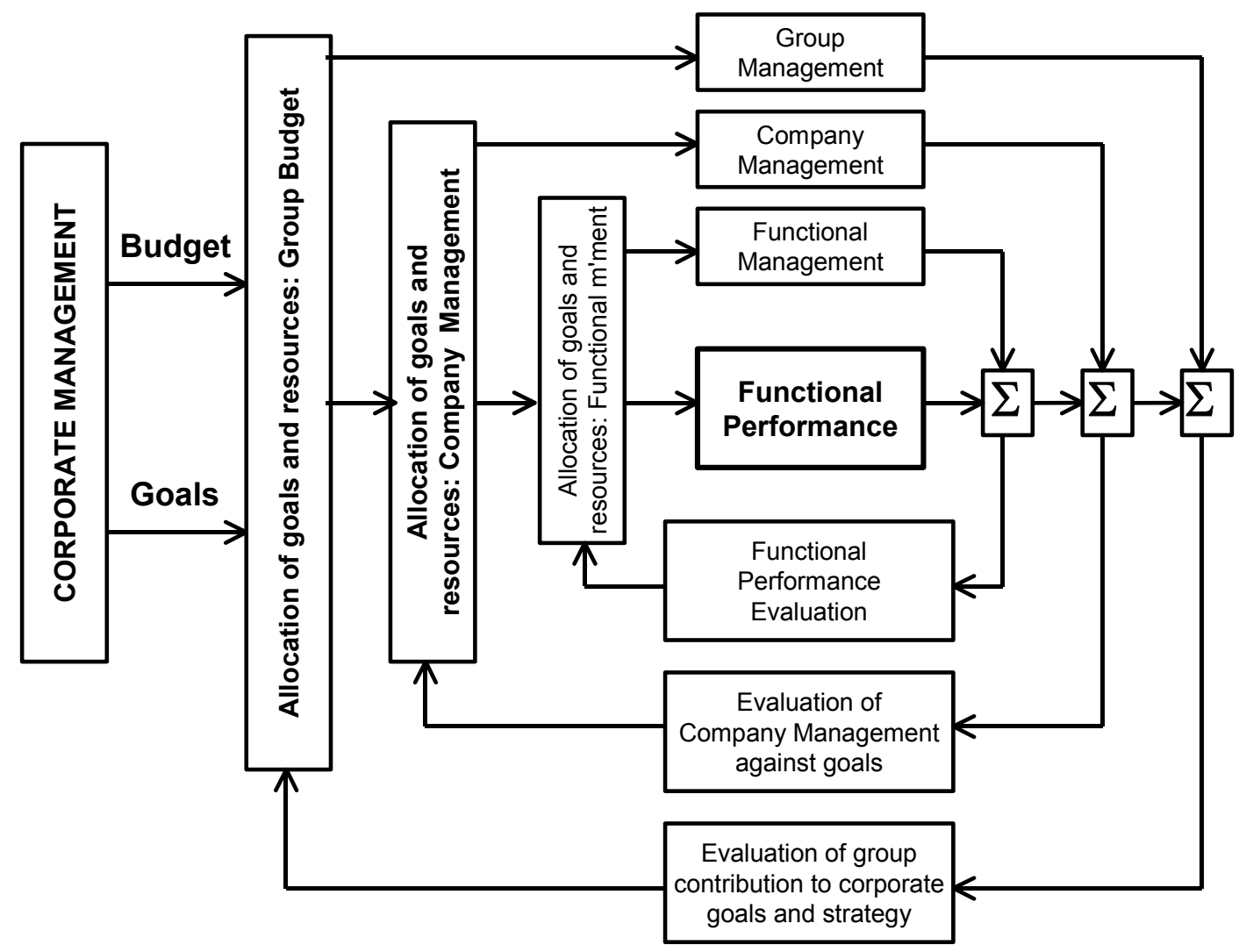

Figure 1: Control system model for a business enterprise

The expanded model now includes a feature like measurement of the resources required to produce the output. It is important that the model also represents the organisational hierarchy or management levels in terms of corporate, strategic business, operational and functional units. For the development of a set of performance indicators, three aspects of the cybernetic management model are of great importance, namely:

- The chosen indicators must be defined in such a way that that the enterprise system will be optimised through the feedback characteristics of the organisational structure

- The specific design of the enterprise hierarchy dictates the positioning of the indicators within the enterprise organisational structure

- The concept of the enterprise as a process where specific inputs are processed to give specific outputs. The purpose of performance indicators will be to measure actual achievements against the set goals, throughout the total process and its sub-processes

Dwight [2] defines performance as "the level to which a goal is attained". The overall objective is to measure performance at the strategic level, based on what is possible. The organisation removes resources from the environment at a cost to it, and translates them into future wealth, or value for the organisation. The resources are transformed into the potential to obtain revenue. The requirement to convert forecasts into a calculation of value requires 
some effort. An alternative approach is to focus on the system and its attributes rather than specific outcomes. This is termed a 'system audit approach' by Dwight.

Tsang [3] emphasises that performance measures need to be positioned in a strategic context, as they influence what people do. Performance measurement is not only required for control and for making better decisions, but it can guide people towards making decisions and organising their work to be consistent with the corporate strategy. If performance measures are to trigger effective beneficial change, they have to fulfil two conditions:

- They should relate to what can be controlled by the system being measured

- They should contribute to specific business success factors

\section{THE MAINTENANCE SYSTEM}

The maintenance system is usually a subsystem of the production or manufacturing system which is a subsystem of the enterprise system. The maintenance system can be represented by the input-output model as discussed in the previous paragraph. The maintenance system can be viewed as an open and dynamic system where resources are used to produce certain outputs of higher value through a transformation process. The maintenance system should react according to changes or disturbances in the inputs, required production outputs, environment and the transformation process.

This transformation process involves maintenance tasks at the lowest level (e.g. adjust, repair, replace) as well as maintenance tactics at higher levels (use-based maintenance, conditionbased maintenance, redesign). An input-output model for the maintenance system as formulated by Visser [4] is illustrated in figure 2 .

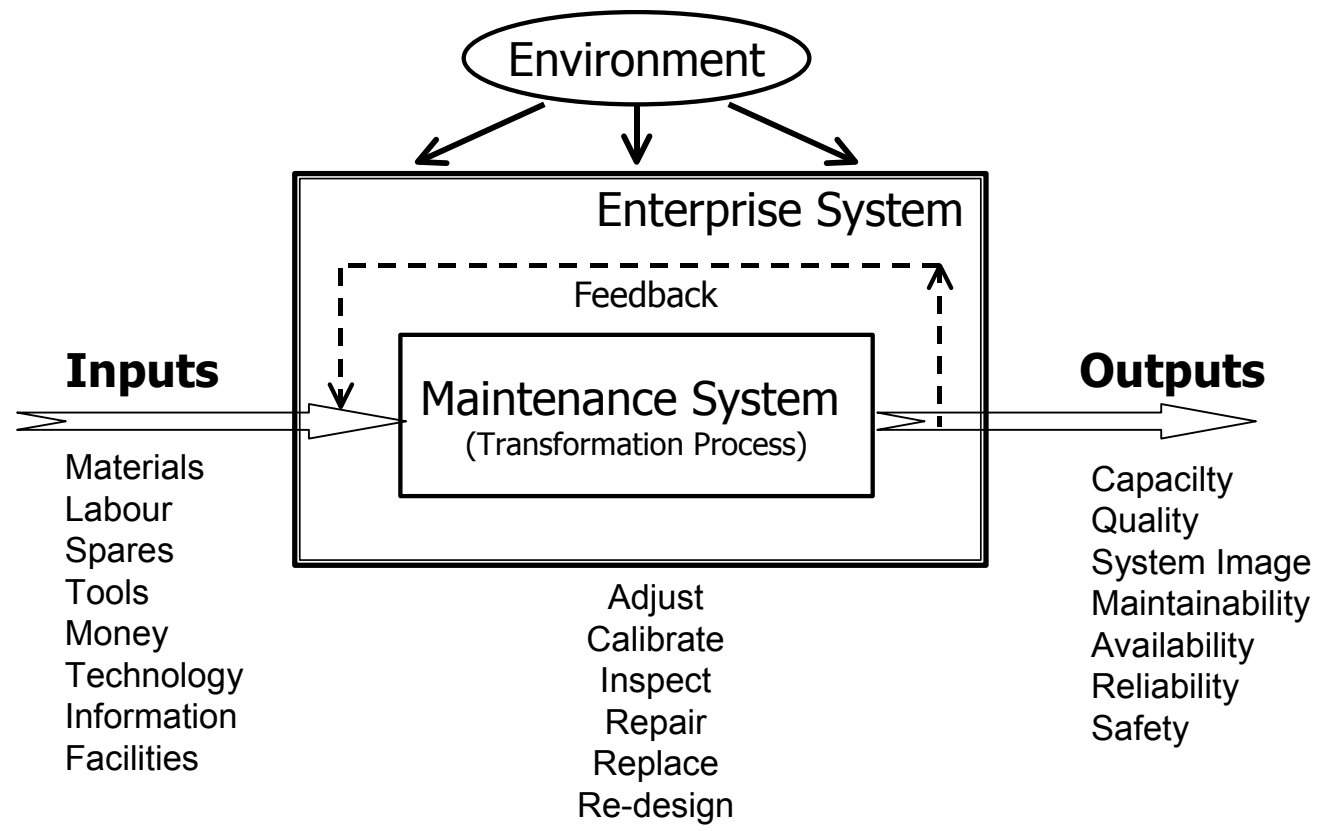

Figure 2: Input-output model for the maintenance system

The inputs to the maintenance process are the resources, typically the workers, spares, materials, information, facilities. Money is needed to pay for the other inputs to the process. 
Two crucial questions can be asked concerning this model, namely:

- what are the real outputs of the maintenance transformation system?

- how should the performance of the overall maintenance system be measured?

The goal of maintenance can be formulated in many ways, for example Kelly [5] says that the maintenance objective is "to achieve the agreed output level and operating pattern at minimum resource cost within the constraints of the system condition and safety". Pradhan [6] feels that the goal of maintenance is "to provide capacity". There appears to be general consensus that the goal of maintenance is to ensure that the technical systems or assets of a company provide the capacity that it was designed for. The desired output or capacity can only be achieved through high availability which is a function of reliability and maintainability. Maintenance is also partly responsible for safe operation of the technical system and to ensure that the system is kept in a good condition, i.e. an acceptable system image. These factors represent the most important output parameters although the maintenance department is not solely responsible for all. The production or operations department and others can also influence factors such as availability and safety.

The outputs are various performance parameters that are related to the inputs in some way. The outputs of the maintenance system is somewhat difficult to define since many of the 'traditional' output parameters such as availability, reliability and safety, are not the sole responsibility of the maintenance system. The operators also have an influence on these performance parameters. Changes to the inputs, the maintenance transformation process, or the environment will cause changes in the outputs of the maintenance process. If the inputs to the maintenance system are reduced, for example the human resources or money, and the outputs have to remain the same, some changes to the maintenance transformation process are required.

\section{PERFORMANCE OF THE BUSINESS ENTERPRISE}

Large business enterprises cannot be managed without indicators of the corporate performance. Such indicators are usually defined as part of the strategic planning process and are derived from the vision and mission statements of the enterprise. Tsang [3] as well as Wireman [7] discuss the importance of linking performance of a functional area, such as maintenance, to the goals and performance measures of the business enterprise.

The Balanced Scorecard (BSC) methodology developed by Kaplan and Norton [8] is a vehicle that translates a business unit's vision, mission and strategy into a set of objectives and quantifiable measures that are built around four perspectives, i.e. financial, customer, internal processes and learning and growth. The way in which the Balanced Scorecard links the strategic objectives, performance measures and targets to strategy was presented by Tsang [3] as indicated in figure 3 . 


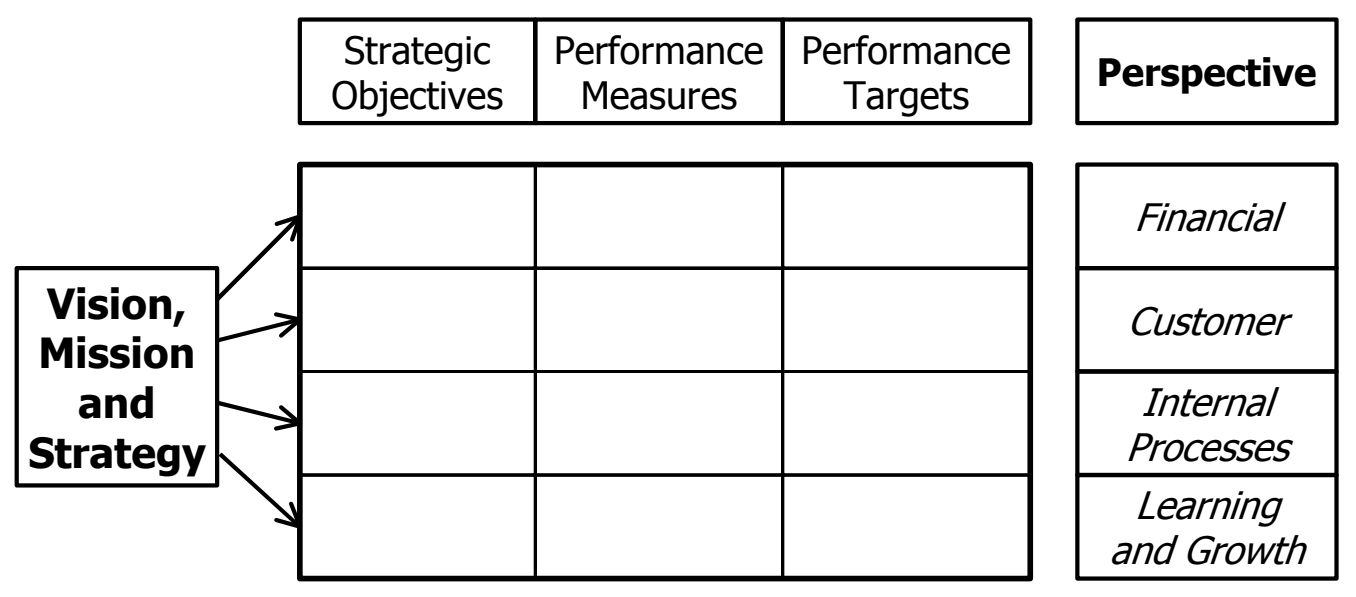

Figure 3: The Balanced Scorecard and links to strategy

The corporate vision, mission and strategy are broken down into a vision, mission and strategy for the maintenance department. This is then used to derive strategic objectives, performance measures and targets for the maintenance department. Any enterprise should design and formulate top-level performance indicators that satisfy at least the perspectives given above.

\section{A PROCESS TO DEVELOP A MAINTENANCE PERFORMANCE SYSTEM}

The development of a maintenance performance measurement system does not comprise a mere selection of a number of performance indicators from published literature. A systematic, top-down approach is needed to design a maintenance performance system. A 6-step process to develop a maintenance performance system is proposed in figure 4 .

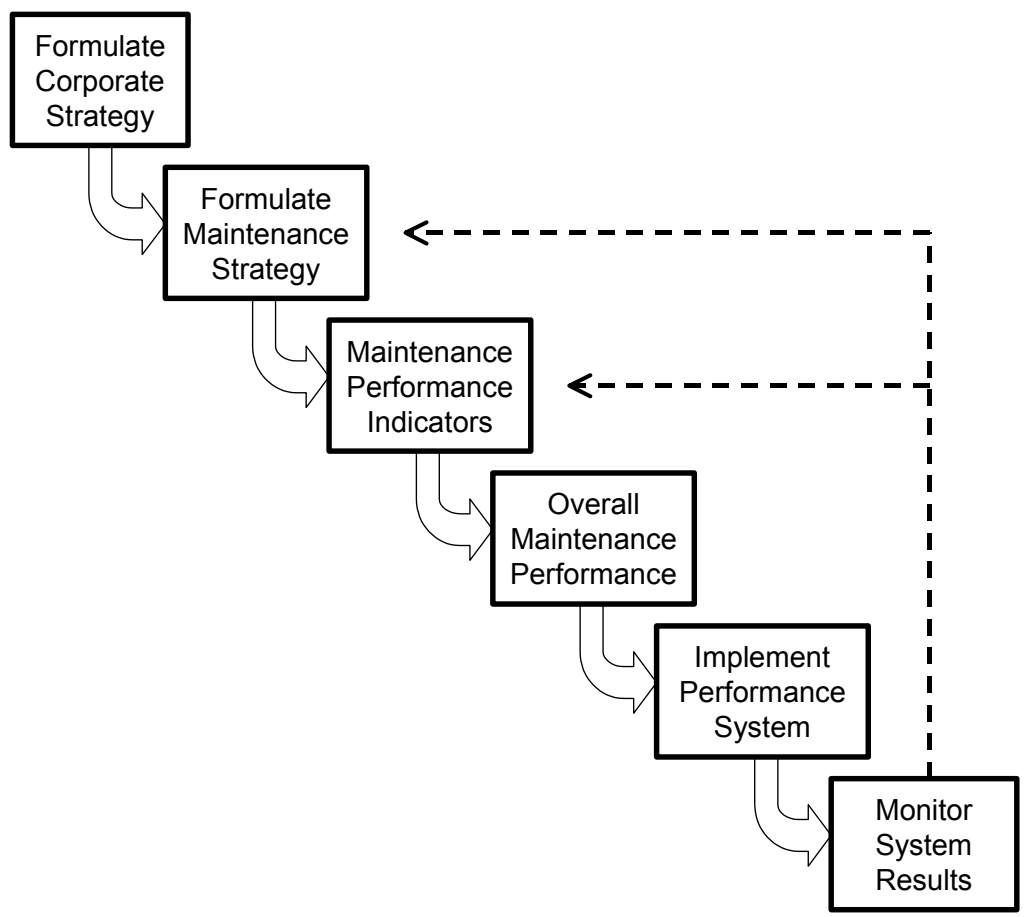


Figure 4: Process for developing a maintenance performance system

The corporate vision and goals are not static and the procedure outline in figure 4 should therefore be applied annually to incorporate any changes if necessary. Usually a company does not change its measurement parameters too often and the maintenance parameters could be used for a number of years. Each of the six steps is now discussed in more detail.

\subsection{Formulate a corporate strategy}

If a corporate strategy does not exist the starting point for the development of a performance system for maintenance is the formulation of the corporate strategy. This involves the strategic management process that most enterprises perform every 2-3 years, or annually.

Pearce and Robinson [9] view strategy at the enterprise level as "a company's large scale, future-oriented plans for interacting with the competitive environment to achieve company objectives". Three levels of strategy are defined, namely at the corporate, business and functional levels. Strategies for functional areas such as operations or maintenance are at the functional level and support the overall strategies at the business and corporate levels. The strategic management process of Pearce and Robinson [9] is summarised in figure 5.

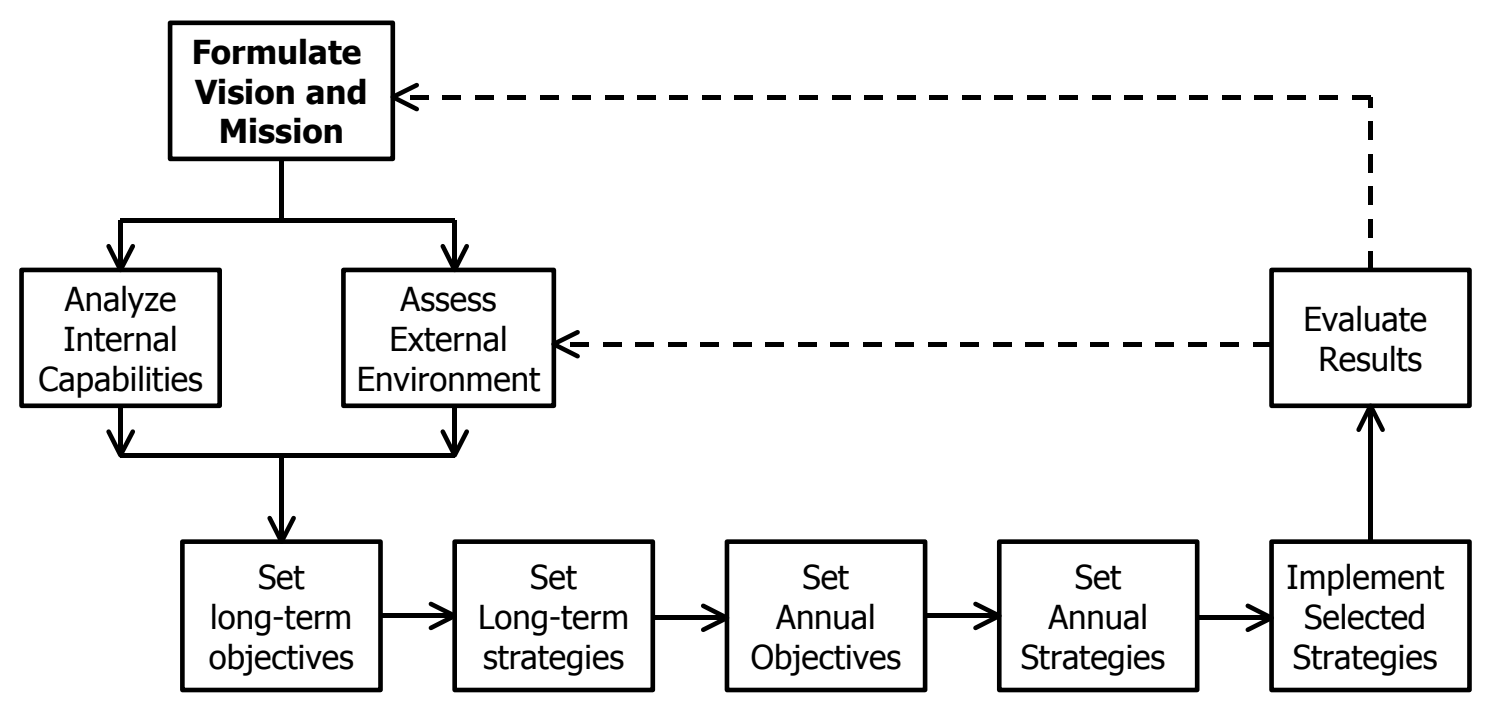

Figure 5: Outline of the strategic management process

The strategic management process starts with a formulation of the vision and mission of the business enterprise. An analysis of capabilities and the environment leads to the formulation of key objectives, long-term as well as short-term. The final step involves the implementation of selected strategies and on-going monitoring of the total process.

\section{Vision and mission}

The vision statement is a brief description of the 'dream' that the company pursues. This 'dream' provides the energy and motivation for the employees to increase performance. Two examples of general vision statements are: 
- "We shall put a man on the moon and bring him back before the end of this decade" (Pres. JF Kennedy, 1963)

- "To improve the economic well-being and quality of life of all stake-holders" (Steven Covey [10])

The vision of the company is important, but the process to formulate the vision is even more important and should involve all stakeholders of the company.

\section{Internal activities and the external environment}

The business enterprise is concerned with internal activities as well as the external environment and an analysis of this is usually called a SWOT analysis. An analysis of the internal activities involves determining a profile of the strengths and weaknesses of the company and the resources that it has at its disposal. The external environment (economic, political, legal, social and natural) cannot be controlled but should be analysed to determine the threats and opportunities that changes can have for the company.

\section{Set long-term objectives}

Using the outputs of the SWOT analysis the next step of strategy formulation involves setting long-term goals and key objectives. Typical key objectives that also address the balanced scorecard elements for a company could be:

- $20 \%$ profit on turnover (financial focus)

- $80 \%$ Customer satisfaction index (customer focus)

- ISO 9001 or ISO 14001 rating (internal processes focus)

- $80 \%$ skilled workers (learning and growth focus)

\section{Strategy to achieve long-term objectives}

Having defined what key objectives to pursue, the next step is to formulate a strategy on how to achieve these objectives, using all the role players necessary for decision-making. The strategy comprises plans that outline in detail how the key objectives are to be achieved.

\subsection{Formulate a maintenance strategy}

The general strategic management process as outlined in figure 5 should now also be used for the maintenance division. The corporate strategy is the major input in the formulation of a maintenance strategy. The main purpose of maintenance is to provide output capacity or service but the following factors should also be taken into account.

- Design life of the asset

- Safety to the personnel and assets

- Quality of the products or services

- System condition or 'shine' 


\section{Vision and mission for maintenance}

The strategic management process for the maintenance division also starts with a vision. The vision is complemented with mission statements or elements that define the unique purpose of the maintenance department, the type of service that must be delivered, and to whom (customers) the service must be delivered. Typical examples of vision statements for maintenance are:

- To be a World Class maintenance department/ section

- To win the SAMA (Southern African Maintenance Association) excellence award

- To achieve a golden/silver or bronze SAMA Maintenance Excellence Certificate

The purpose of the mission statement for maintenance is:

- to state clearly what the maintenance department wants to achieve

- to provide a basis for allocating the maintenance resources

- to establish a specific culture within the maintenance department

\section{Key objectives and strategies}

Objectives can be general statements of specific goals that are to be achieved. Typical examples of such objectives are:

- Reduce the cost of maintenance

- Increase the reliability, maintainability and availability

- Increase plant safety

- Develop maintenance personnel through training

\subsection{Identify and select a set of maintenance performance indicators}

Having identified broad objectives for maintenance, the next step involves the selection of a balanced set of maintenance performance indicators. This selection or definition of maintenance indicators is not a trivial task and it is important not to select a number of indicators from published literature in a more or less random way. A balanced set of maintenance indicators is required that addresses all aspects of the maintenance function. Selection of maintenance indicators should be based on a number of criteria as discussed in the following paragraphs.

\section{Strategic relevance}

Overall corporate performance indicators are needed in any business enterprise to ensure that the company is being managed well and that the company is remaining in a competitive situation. Such indicators are usually defined as part of the strategic planning process and are derived from the vision and mission statements of the enterprise. The vision, mission and business goals should be aligned with the needs and expectations of the customers as discussed by Tsang [3] and Wireman [7]. Chang and Morgan [11] also emphasised the 
importance of linking the performance indicators in a functional area, such as maintenance, to the overall corporate goals and performance measures.

Performance indicators for the maintenance department should therefore contribute towards the corporate performance indicators. Not all maintenance indicators will contribute directly to the overall indicators, but some measurements taken during the execution of maintenance will be used for the calculation of the corporate indicators. A corporate indicator for profit as a ratio of turnover indicates the importance of cost and the ratio of maintenance cost over total cost of manufacturing is a logical choice to contribute towards the corporate indicator.

\section{Input-Output Model for Maintenance}

Considering the input-output model of the maintenance system as indicated in figure 2 performance measurement for the maintenance system should measure aspects of the inputs to the process, the conversion or transformation process, and the outputs of the process. It should be remembered that some of the more traditional outputs of the maintenance function, for example availability and reliability, are actually outputs of the manufacturing or production system.

The maintenance manager would like to know how well the inputs are used to add value to the overall production or manufacturing function. A balanced set of maintenance performance indicators should therefore have indicators for measuring the labour, money, spares tools, etc., usually as ratios of labour and money being used in the overall company. Other effectiveness indicators are required to measure the process itself, for example the ratio of preventive or corrective maintenance over total maintenance effort, usually measured in time units. Typical outputs of the maintenance system that are under the control of the maintenance manager are maintainability and system image.

\section{Balanced Scorecard Perspective}

The balanced scorecard perspective as mentioned in paragraph 4 is a good starting point for the definition and selection of maintenance indicators. Four perspectives were proposed for company performance indicators and these same perspectives can also be used for the maintenance system. These perspectives, with application to maintenance, are:

- Financial perspective - how the maintenance department should add value to the technical system in a cost-effective way

- Customer perspective - how the maintenance department should appear to its main customer, i.e. the operations or production department, to achieve its vision

- Internal business processes - what maintenance processes or activities must the maintenance department excel at to satisfy the operations department, for example well executed preventive maintenance

- Learning and growth - how the maintenance department will sustain its ability to change and improve through a culture of life long learning to increase skill levels and learn new skills as the technology of doing maintenance changes or improves 
A balanced set of maintenance indicators should therefore satisfy most or all of these balanced scorecard perspectives.

\section{Functional classification}

The maintenance function or operations can be divided into a number of sub functions or functional areas as proposed by Wireman [7]. He defined a total of eleven categories for three levels of the total hierarchy of indicators, namely efficiency/effectiveness, tactical and functional maintenance performance indicators. A balanced set of maintenance indicators should cover the most important of these categories, for example:

- Preventive maintenance

- Inventory and procurement

- Work order systems

- Computerised maintenance management systems

- Technical and interpersonal training

\subsection{Define Overall Maintenance System Performance}

The next step in developing a performance measurement system for maintenance is to define the overall performance. Tompkins and Associates [12] give an example of determining an overall maintenance performance as part of the Scoreboard for Maintenance Excellence. The overall performance is useful as an early indicator of problems and is therefore recommended for any maintenance system. Overall performance can be defined as a linear combination of the product of a number of performance indicators and weight factors. The following equation to define Total Maintenance Performance (TMP) can therefore be used.

$$
T M P=\sum_{i}^{n} W_{i} \cdot B_{i}
$$

In equation 1 the variable $B_{i}$ represents the benefit value of individual performance parameters, for example worker utilisation, availability, reliability, etc. The variable $W_{i}$ represents weight factors to indicate the relative importance of the performance parameters. It is recommended that $8-12$ performance indicators or parameters be used to define and calculate the total maintenance performance, TMP. Whereas the Tompkins model uses tables to determine the score or benefit for each indicator, it is easier to define a benefit function or equation for each selected parameter. An example of a typical benefit function for Availability and Preventive Maintenance Ratio is given in figure 6. 

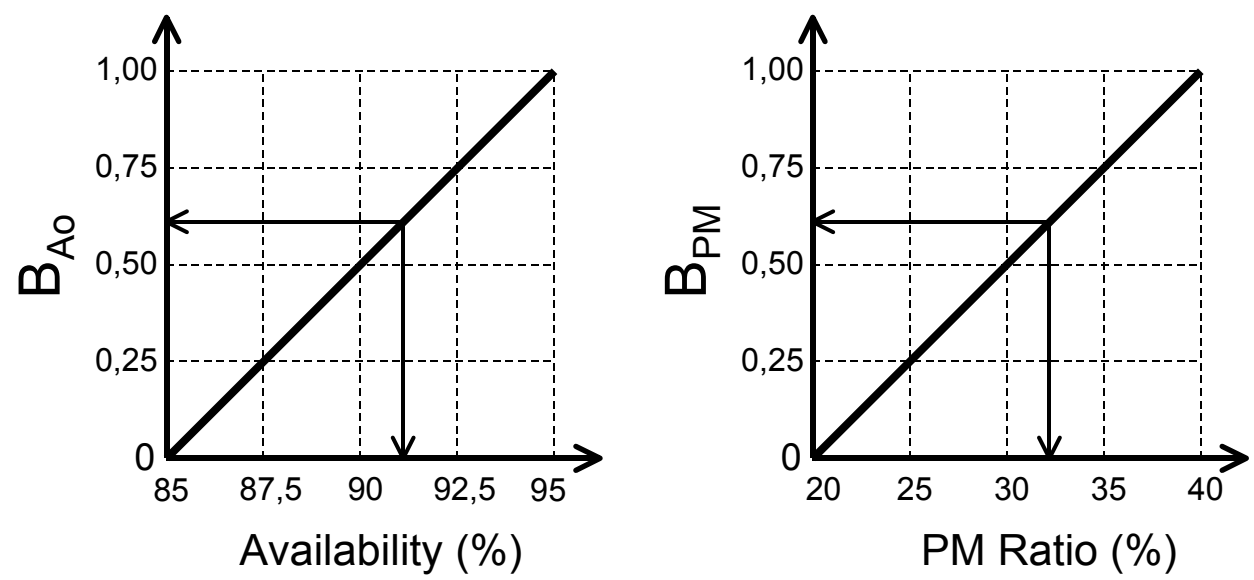

Figure 6: Example of a benefit function for availability and PM ratio

The benefit function transforms the value of a parameter to a normalised value between 0 and 1 (or 0 and $100 \%$ ). The benefit, $B$, can also be expressed as a mathematical formula that will facilitate easy calculation by means of a spreadsheet, for example:

$B=m \cdot x+c$

where $x$ is the performance parameter, for example maintenance cost, and $m$ and $c$ are the parameters of the straight line. In some cases the relationship is not a simple straight line since there could be an optimum value between a minimum and maximum.

A performance measurement system should address the right evaluation parameters to give consistent results. The maintenance manager must feel confident that the performance system will indicate whether he is improving in the management of the maintenance system (division or department) or not. An example of the calculation of the total maintenance performance, using nine performance parameters, is given in table 1.

\begin{tabular}{|l|c|c|c|c|c|c|}
\hline Maintenance Indicator & $\boldsymbol{W}_{\boldsymbol{i}}$ & Minimum & Maximum & Value & $\boldsymbol{B}_{\boldsymbol{i}}$ & $\boldsymbol{B}_{\boldsymbol{i}} \cdot \boldsymbol{W}_{\boldsymbol{i}}$ \\
\hline Availability (\%) & 15 & 85 & 95 & 91 & 0.60 & 0.090 \\
\hline MTBF (hours) & 15 & 100 & 200 & 165 & 0.65 & 0.098 \\
\hline PM Ratio & 15 & 20 & 40 & 32 & 0.60 & 0.090 \\
\hline Maintenance Cost Ratio & 15 & 10 & 30 & 24 & 0.30 & 0.045 \\
\hline Maintenance Errors (\%) & 10 & 0 & 10 & 2 & 0.80 & 0.080 \\
\hline Store Turns Ratio & 5 & 0.8 & 1.2 & 1.1 & 0.75 & 0.038 \\
\hline Stores Service Level (\%) & 10 & 80 & 100 & 97 & 0.85 & 0.085 \\
\hline Personnel Cost Ratio (\%) & 5 & 30 & 40 & 32 & 0.80 & 0.040 \\
\hline System Image (\%) & 10 & 50 & 100 & 85 & 0.70 & 0.070 \\
\hline $\begin{array}{l}\text { Total Maintenance } \\
\text { Performance, } \boldsymbol{T M P}\end{array}$ & & & & & $\mathbf{0 . 6 3 5}$ \\
\hline
\end{tabular}

Table 1: Example of the calculation of Total Maintenance Performance, TMP 
The total maintenance performance, $T M P$, in this specific example is 0,635 or $63,5 \%$. This value should be monitored and tracked on a regular basis, typically monthly. It is recommended that such a total performance value should be determined since it is a measure of how the total maintenance system is performing. A decrease for a number of periods would be an early indicator of problems and individual parameters could then be evaluated to determine the cause of the decrease in TMP.

\subsection{Implement Maintenance Performance System}

Having defined a coherent set of maintenance performance indicators, the next step involves the implementation of the performance system for the maintenance division responsible for the maintenance of a technical system. Although a computerised information system is not essential, it will be much easier and quicker if the data for the calculation of the performance indicators are captured by means of a computerised system. Basic data that is captured by means of work orders, stores requisitions, receipts and other raw documents could include:

- Time that item/unit failure takes place

- Time that maintenance on item/unit is started

- Time that maintenance on item/unit is finished

- Time that item/unit is restarted

- Time for faultfinding on item/unit (hours)

- Time waiting for spares (hours)

- Actual production output per period (ton/hour)

- Number of parts of specific type issued

\subsection{Monitor Results}

Once implemented, the maintenance manager will obtain actual values for the performance parameters on a regular basis. Graphical representation of this data is recommended to determine trends in the data. The concept of Performance Scorecards was developed by Chang and Morgan [11] to monitor the results of performance measurement. The basic idea suggested by Chan and Morgan for monitoring performance of the company was adapted for the maintenance department. An example for a typical maintenance department that incorporates the most critical measures is illustrated in figure 7. This example shows five indicators, namely:

- Availability

- Mean-time-between-failure

- Maintenance cost/Total production cost

- Preventive maintenance time/Total maintenance time

- System image

Each maintenance department of a company should determine its most critical performance measures and develop a scorecard for these measures.

The Performance Scorecard, presented on a page or two, indicates graphically what the trend in performance was in the last two or three years as well as in the months of the current 
financial year. The maintenance manager can therefore easily identify trends and take the necessary actions to ensure that performance targets are met.

\section{Maintenance Department Performance Scorecard}

\section{Key Objectives for 2001}

- Increase availability to $91 \%$

- Increase MTBF to $185 \mathrm{~h}$

- Decrease Mtce Cost to $25 \%$

- Increase PM Ratio to 34\%

- Increase system image to $94 \%$
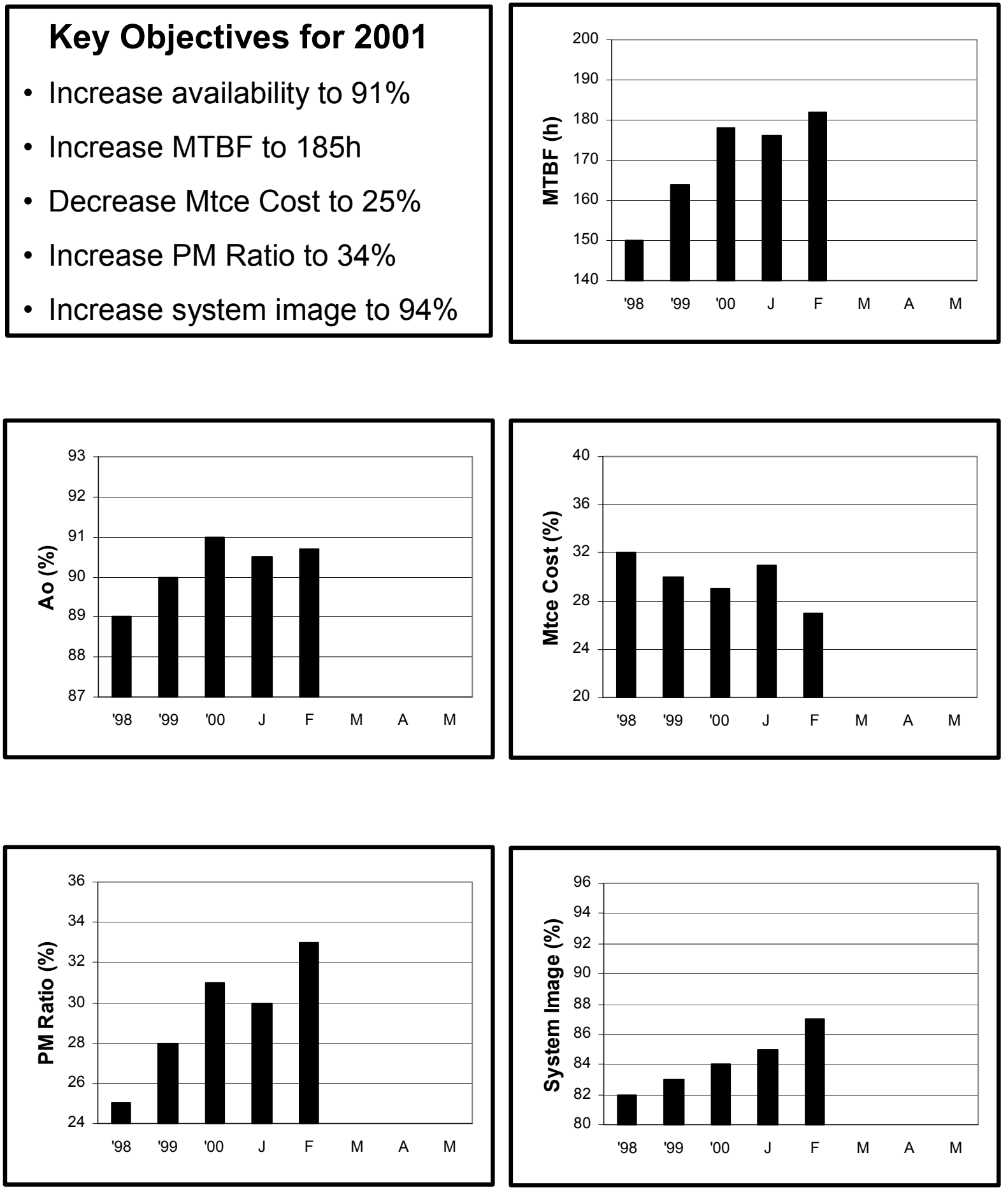

Figure 7: Example of Performance Scorecards for maintenance 


\section{CONCLUSIONS}

The maintenance system or department is an important subsystem of the business enterprise that can influence the profitability of the company significantly. It is therefore of utmost importance that the performance of the maintenance system should be monitored and optimised within the context of the total business enterprise performance.

A performance measurement system for maintenance should be designed in a top-down way, starting with the strategy, objectives and performance parameters of the business enterprise. A systematic six-step process for the development of the maintenance performance system is proposed.

Maintenance performance indicators should be selected to provide a balanced set of indicators that address different functional and effectiveness areas. The trends in total maintenance performance, as well as individual parameter performance, can be represented by means of the Performance Scorecard technique.

\section{REFERENCES}

[1] De Wet, G., 1995, A Cybernetic Systems Perspective on Management, CSIR Working Paper, PSU-02-0695

[2] Dwight, R., 1999, Searching for real maintenance performance measures, J. of Quality in Maintenance Engineering, 5, (3), pp258-275

[3] Tsang, A.H.C., Jardine, A.K.S. and Kolodny, H., 1999, Measuring maintenance performance: a holistic approach, Int. J. of Operations and Production Management, 19 (7), pp691-715

[4] Visser, J.K., 2001, Maintenance Performance Indicators For An Underground Mine, Proc. of the Internationl Conference of Maintenance Societies (ICOMS-01), MESA, Melbourne, Australia

[5] Kelly, A., 1989, Maintenance and its Management, Conference Communication, London

[6] Pradhan, S., 1994, Maintenance Strategies for Greater Availability, Hydrocarbon Processing, 73 (1), pp39- 44

[7] Wireman, T., 1998, Developing Performance Indicators for Managing Maintenance, Industrial Press, Inc., New York, 195 pages

[8] Kaplan, R.S. and Norton, D.P., 1996, Using the Balanced Scorecard as a Strategic Management System, Harvard Business Review, 74, (1), pp75-85

[9] Pearce, J.A. and Robinson, R.B., 1994, Strategic Management: Formulation, Implementation and Control, $5^{\text {th }}$ Edition, Irwin, Illinois, 935 pages

[10] Covey, S., 1992, Principle Centered Leadership, Simon \& Shuster, London, 332 pages

[11] Chang, R.Y. and Morgan, M.W., 2000, Performance Scorecards: Measuring the Right Things in the Real World, Jossey-Bass Inc. Publishers, San Francisco

[12] Planning for Maintenance Excellence, Document M-33, Tompkins Associates Incorporated, 2809 Millbrook Road, Raleigh, NC 27616, USA (www.tompkinsinc.com) 
